\title{
Lymphocyte subpopulations in thymus and blood from patients with myasthenia gravis
}

\author{
J OHA NA. A ARLI, PETER HEIMA N N*, ROALD MATRE, \\ SVEIN THUNOLD, A N D O A V TÖNDER \\ From the Departments of Neurology, Surgery, and Pathology, and the Broegelmann Research \\ Laboratory for Microbiology, School of Medicine, University of Bergen, Norway
}

SUMMARY Cell suspensions were prepared from hyperplastic thymic tissue and lymphoepithelioma from patients with myasthenia gravis and from presumed normal thymic tissue obtained at cardiac surgery. The mononuclear cells were examined for surface markers. The mean percentages of both $\mathrm{T}$ lymphocytes and $\mathrm{Fc}$ receptor-carrying lymphocytes were similar in the three groups, whereas there was an increase in $\mathrm{C}$ receptor-carrying lymphocytes in the samples from myasthenic patients. Sections from the thymus gland were examined for $\mathrm{T}$ and $\mathrm{B}$ markers. In the hyperplastic thymus and in lymphoepithelioma, the $T$ lymphocytes were distributed diffusely throughout the cortex and the medulla; in the normal thymus they were predominant in the cortex. The mean percentage of $\mathrm{T}$ and $\mathrm{B}$ lymphocytes in peripheral blood from patients with myasthenia gravis was normal. Thymectomy involved a transitory decrease in $\mathrm{T}$ lymphocytes with a corresponding increase in B lymphocytes.

The rapid variation of the muscular weakness in myasthenia gravis is commonly ascribed to the blocking effect of circulating antibodies against the acetylcholine receptor protein of the muscle endplate (Lindstrom et al., 1976), while the long-term structural changes may also be caused by the effect of sensitised lymphocytes (Richman et al., 1976). The neuromuscular symptoms of myasthenia gravis can, therefore, be regarded as the result of a combined humoral and cellular immune response towards antigenic determinants in the muscle endplate.

The thymus gland, which has a central role in the development of cellular immune competence, is frequently histologically abnormal in myasthenia gravis, and thymectomy can result in a significant clinical improvement. A few recent reports indicate an alteration in the distribution of $T$ and $B$ lymphocytes within the thymus in myasthenia gravis, but the data are conflicting (Abdou et al., 1974; Lisak et al., 1976; Shirai et al., 1976). The aim of the present work was, therefore, to investigate whether myasthenia gravis is accompanied by a disturbance in the distribution and relative

Address for reprint requests : Professor Johan A. Aarli, Department of Neurology, 5016 Haukeland sykehus, Bergen, Norway.

*Deceased.

Accepted 4 July 1978 quantities of $\mathrm{T}$ and $\mathrm{B}$ lymphocytes in the thymus, and if removal of the thymus has any effect upon $\mathrm{T}$ and $\mathrm{B}$ lymphocyte levels in the blood.

\section{Materials and methods}

\section{PATIENTS}

The patients were being treated for myasthenia gravis at the Department of Neurology. Thymectomy was performed at the Department of Surgery by the transthoracic approach. There were two patients with thymoma. One of these (MG 45) had received a seven days course of ACTH treatment (1000 iu) two months before the operation. With this exception, ACTH, steroids, or immunosuppressive drugs were not administered before thymectomy.

\section{THYMUS}

Immediately after thymectomy, parts of the organ were prepared for routine histology. Suitable pieces of the tissue were quick-frozen in liquid nitrogen for the preparation of cryostat tissue sections. The remaining tissue was minced with scissors and centrifuged at $100 \mathrm{~g}$ for $1 \mathrm{~min}$ to separate the coarser particles. The cells in suspension (thymocytes) were then washed three times in isotonic, phosphate-buffered saline, pH 7.2 (PBS). Thymic 
tissue obtained at cardiac surgery was used as control.

PERIPHERAL BLOOD LYMPHOCYTES

Two millilitres of PBS were added to $2 \mathrm{ml}$ of heparinised venous blood $(10 \mathrm{iu} / \mathrm{ml})$. The mixture was carefully layered on $3 \mathrm{ml}$ of Lymphoprep (Nyegaard and Co., Oslo, Norway) and the mononuclear cells were separated by gradient centrifugation (Böyum, 1968). The cells were washed three times in PBS and kept at $4^{\circ} \mathrm{C}$ until use. The trypan blue exclusion test showed $95 \%$ viable cells.

DEMONSTRATION OF SURFACE MARKERS ON CELLS IN SUSPENSION

$\mathrm{T}$ cells were enumerated by the rosette assay with sheep erythrocytes (E) (Jondal et al., 1972). Briefly, $0.1 \mathrm{ml}$ of a cell suspension containing $2 \times 10^{\circ}$ cells $/ \mathrm{ml}$ was mixed with an equal volume of a $1 \%$ suspension of sheep erythrocytes in PBS containing $20 \%$ fetal calf serum absorbed with sheep erythrocytes. After incubation at $37^{\circ} \mathrm{C}$ for $5 \mathrm{~min}$, the cell mixture was centrifuged at $200 \mathrm{~g}$ for $5 \mathrm{~min}$. The pellet was gently resuspended by rotating the tube along the long axis, and the percentage of rosette forming cells was counted in a haemocytometer after overnight incubation of the cell mixture at $4^{\circ} \mathrm{C}$.

The indirect immunofluorescence technique was used for the demonstration of surface immunoglobulin (Ig). $0.1 \mathrm{ml}$ of a cell suspension containing $4 \times 10^{6}$ cells was incubated with equal amounts of a fluorescein-conjugated polyvalent rabbit IgG anti-human immunoglobulin (Dakopat, Copenhagen) at room temperature for $30 \mathrm{~min}$. The conjugate was diluted to a final protein concentration of $1.25 \mathrm{mg} / \mathrm{ml}$, equal to 0.5 precipitating units $/ \mathrm{ml}$. The optical density ratio (OD) (OD $495 / 278 / O D$ ) was $0.63 \pm 0.03$ as specified by the manufacturer. The cells were washed three times in PBS, mounted in PBS buffered glycerol and examined for membrane fluorescence with a Leitz orthoplane microscope using epi-illumination (Beutner et al., 1968). Fc receptor positive cells were demonstrated by rosette assay using ox erythrocytes (E) sensitised with rabbit IgG antierythrocytes antibody (A) (Hallberg et al., 1973).

Erythrocytes sensitised with rabbit IgM antierythrocyte antibody and human complement (EAC3b) were used for the demonstration of complement receptor (C3b receptor) positive cells. The erythrocyte-antibody-complement indicator system (EAC) was prepared as described previously (Matre and Tönder, 1976). IgM-EA and E served as controls. Equal amounts of lymphocyte suspension $\left(2 \times 10^{\circ}\right.$ cells $\left./ \mathrm{ml}\right)$ and indicator cells ( $1 \%$ suspen- sion) were mixed and left at room temperature for one hour. After centrifugation at $200 \mathrm{~g}$ for $5 \mathrm{~min}$ and gentle resuspension of the pellet, the number of rosetting cells out of a total count of 200 was counted as for the $E$ test. For all rosette assays, cells binding more than three indicator cells were considered rosetting cells.

DEMONSTRATION OF E, FC, AND C RECEPTORS IN TISSUE SECTIONS

The procedure used was the closed chamber technique as described by Tönder et al. (1974). Diffuse or focal haemadsorption was graded microscopically when the glass around the tissue was free of erythrocytes. The procedure for fixation and staining with haematoxylin and eosin was the same as described previously (Matre and Tönder, 1976).

For the demonstration of $\mathrm{E}$ receptor, the tissue $\overrightarrow{0}$ sections were incubated at $4^{\circ} \mathrm{C}$ overnight using $\vec{\overrightarrow{ }}$ AET-treated sheep erythrocytes in PBS using $25 \% \omega$ heat inactivated fetal calf serum. The slides were then turned over and left at $4^{\circ} \mathrm{C}$ for $15 \mathrm{~min}$. The $\frac{7}{0}$ preparations were studied microscopically while is still cold.

For the demonstration of Fc receptor, the ind $\vec{\sigma} \overrightarrow{0}$ cator cells (EA) were prepared by sensitising sheep erythrocytes with one agglutinating unit of rabb舵 IgG antibodies (A). One agglutinating unit defined as the amount of the highest dilution of antiserum which agglutinates an equal amoung of a $1 \%$ suspension of erythrocytes. EA was suspended in PBS containing 0.5\% normal rabbi $\overrightarrow{\dot{\phi}}$ serum. For the demonstration of $\mathrm{C}$ receptors, the indicator cells (EAC) were prepared as previously described (Matre and Tönder, 1976).

Tissue sections were incubated with EA or with EAC indicator cells for $30 \mathrm{~min}$ at room temperature.

\section{Results}

LYMPHOCYTE MARKERS ON THYMOCYTES IN SUSPENSION

Cell suspensions were prepared using hyperplastic thymic tissue from four patients with myasthenia gravis. $\mathrm{E}$ and $\mathrm{EA}$ rosette tests were performed on all four samples, EAC rosette tests only on cell suspensions from two patients (Table 1).

The mean percentage of $\mathrm{T}$ lymphocytes in suspension was 90 and the range $84-97 \%$ (normal 을 $86 \%$, range $82-90 \%$ ).

The number of Fc receptor positive lymphocytes $\frac{7}{2}$ (EA rosettes) in the thymocyte suspension was in the range of 2 to $14 \%$ with a mean of $7 \%$ (normal $\Omega$ mean $6 \%$ ). Cells with $\mathrm{C} 3 \mathrm{~b}$ receptor (EAC rosettes) $\mathrm{N}$ amounted to $25 \%$ in one sample and $9 \%$ in the 
Table 1 Percentage of thymocytes with $T$ and $B$ lymphocyte markers in thymic tissue from four patients with myasthenia gravis and thymus hyperplasia

\begin{tabular}{lllll}
\hline Patients & $\begin{array}{l}\text { Tlymphocyte } \\
\text { markers (\%) } \\
\text { E rosettes }\end{array}$ & \multicolumn{3}{c}{ B lymphocyte markers $(\%)$} \\
\cline { 3 - 5 } & \multicolumn{5}{c}{$\begin{array}{l}\text { EA } \\
\text { rosettes } \\
\text { (1 aggl. } \\
\text { unit) }\end{array}$} & $\begin{array}{l}\text { C3b } \\
\text { receptor }\end{array}$ & $\begin{array}{l}\text { Surface } \\
\text { Ig }\end{array}$ \\
\hline MG 22 & 97 & 2 & ND & ND \\
MG 38 & 88 & 6 & ND & ND \\
MG 41 & 90 & 7 & 25 & ND \\
MG 46 & 84 & 14 & 9 & $<1$ \\
Normal thymus & & 6 & 6 & $<1$ \\
(mean values) & 86 & 28 & 25 & 14 \\
Normal blood & 75 & & &
\end{tabular}

$\mathrm{ND}=$ not done.

other, which were higher than in normal thymus (mean 6\%).

A small thymoma of the lymphoepithelial type $(15 \times 5 \times 5 \mathrm{~mm})$ was present in the thymus removed from patient MG 45. The tumour was easily dissected free and a tumour cell suspension prepared. Ninety per cent of the cells formed $E$ rosettes, indicating that the tumour consisted mainly of $T$ lymphocytes. Patient MG 44 had an infiltrating lymphoepithelioma, and $92 \%$ of the thymocytes from this tumour formed $\mathrm{E}$ rosettes. The small population of $B$ lymphocytes present in these two tumours seemed to consist mainly of cells with complement receptor (Table 2). On the other hand, the $T$ and $B$ lymphocyte percentages, both in the hyperplastic thymus and the lymphoepithelioma, did not vary from data obtained with apparently normal thymus tissue.

\section{CELL MARKERS IN TISSUE SECTIONS}

When the tissue section technique was performed using normal thymus tissue, the $\mathrm{E}$ indicator cells adhered mainly to the cortex, less to the medulla and not at all to the Hassall's corpuscles. In the thymoma, the $\mathrm{E}$ indicator cells adhered diffusely to the tissue section (Fig. 1a), while the EA and EAC3b indicator cells were scattered throughout the tissue (Fig. 1b). However, the EAC3b adhered

Table 2 Percentage of thymocytes with $T$ and $B$ lymphocyte markers in thymoma (lymphoepithelioma) from two patients with myasthenia gravis

\begin{tabular}{|c|c|c|c|c|}
\hline \multirow[t]{2}{*}{ Patients } & \multirow{2}{*}{$\begin{array}{l}\text { Tlymphocyte } \\
\text { markers }(\%) \\
\text { E rosettes }\end{array}$} & \multicolumn{3}{|c|}{ B lymphocyte markers $(\%)$} \\
\hline & & $\begin{array}{l}E A \\
\text { rosettes } \\
(1 \text { aggl. } \\
\text { unit })\end{array}$ & $\begin{array}{l}\text { C3b } \\
\text { receptor }\end{array}$ & $\begin{array}{l}\text { Surface } \\
\text { Ig }\end{array}$ \\
\hline $\begin{array}{l}\text { MG } 44 \\
\text { MG } 45\end{array}$ & $\begin{array}{l}92 \\
90\end{array}$ & $\begin{array}{l}7 \\
4\end{array}$ & $\begin{array}{l}14 \\
14\end{array}$ & $\begin{array}{l}<1 \\
2-3\end{array}$ \\
\hline
\end{tabular}

mainly to some small areas in the tumour (Fig. 1b) which did not bind E (Fig. 1a) or EA indicator cells. The nature of the cells within these areas could not be identified with certainty in frozen sections stained with $\mathrm{H}$ and $\mathrm{E}$. Definite germinal centres were not detected in frozen sections of the thymoma.

\section{PERIPHERAL T AND B LYMPHOCYTES}

Pre-thymectomy values

$\mathrm{E}, \mathrm{EA}$, and EAC rosette tests were performed using suspensions of peripheral blood lymphocytes from seven myasthenia gravis patients before thymectomy. The number of $\mathrm{E}$ rosetting lymphocytes was within the normal range (58 to $73 \%$ ) in all patients, and the mean was $68 \%$. The mean percentage of EA rosette-forming lymphocytes was $22 \%$ (range 12 to $31 \%$ ). EAC rosette-forming lymphocytes varied from 13 to $50 \%$, (mean $27 \%$ ). Except for a high number of EAC rosette-forming lymphocytes in one patient, who also had an adenocarcinoma of the colon, the numbers of circulating $T$ and $B$ lymphocytes were within the normal range in all patients.

\section{Post-thymectomy values}

Peripheral blood was drawn from the patients two and six days after the thymectomy, and then at irregular intervals during the first two to 12 weeks after operation. E and EA rosette tests were performed on all samples, EAC rosette tests on five (MG 41, 42, 44, 45, and 46).

In all samples, the percentage of $E$ rosetting lymphocytes was slightly decreased, and the number of EA rosetting lymphocytes increased. The fall in the first population corresponded grossly to the increase in the second population (Fig. 2). Also, EAC rosette-forming lymphocytes and Igpositive lymphocytes increased in numbers which corresponded to the moderate increase in EA rosetting lymphocytes. The changes in the relationship between the cell populations were transitory, since the percentage of E, EA, and EACforming lymphocytes two to three months later were approximately identical with preoperative values.

Blood was also obtained from three female patients who underwent thymectomy three, seven, and nine years previously, and who had full remission of clinical symptoms. The percentage and absolute numbers of T lymphocytes, EA, EAC3brosetting, and surface Ig-lymphocytes were normal.

\section{Discussion}

Approximately $90 \%$ of the cells from sus- 


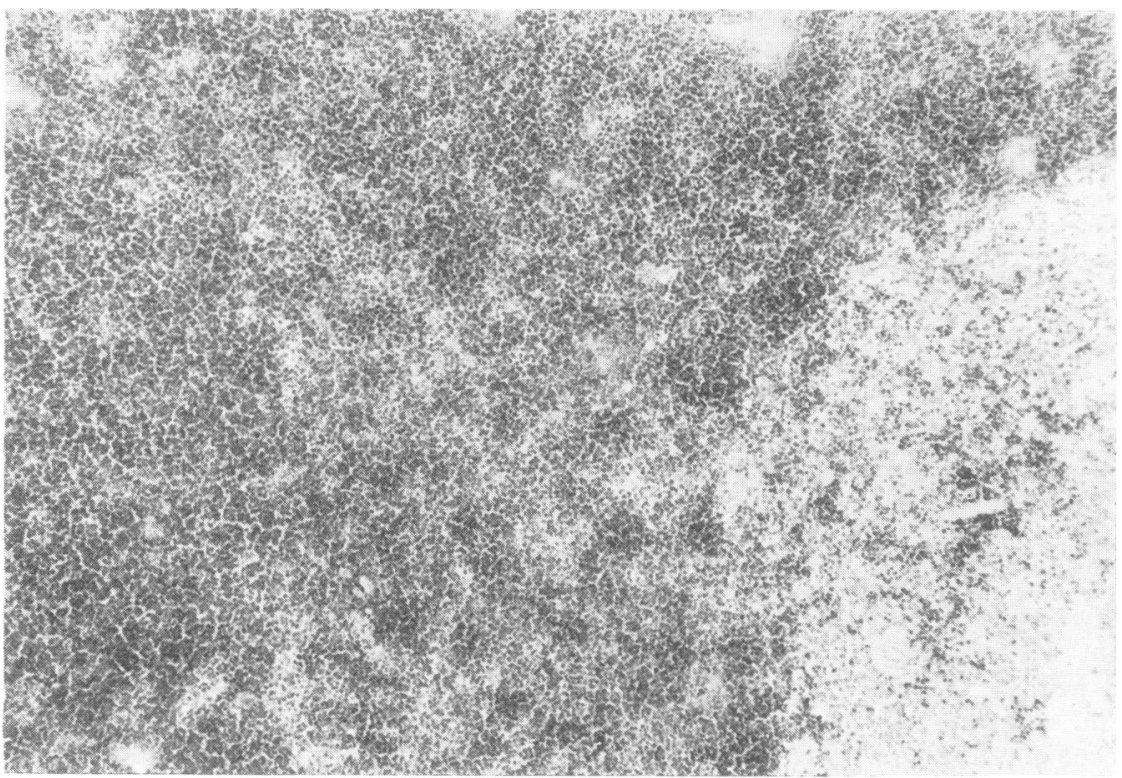

(a)

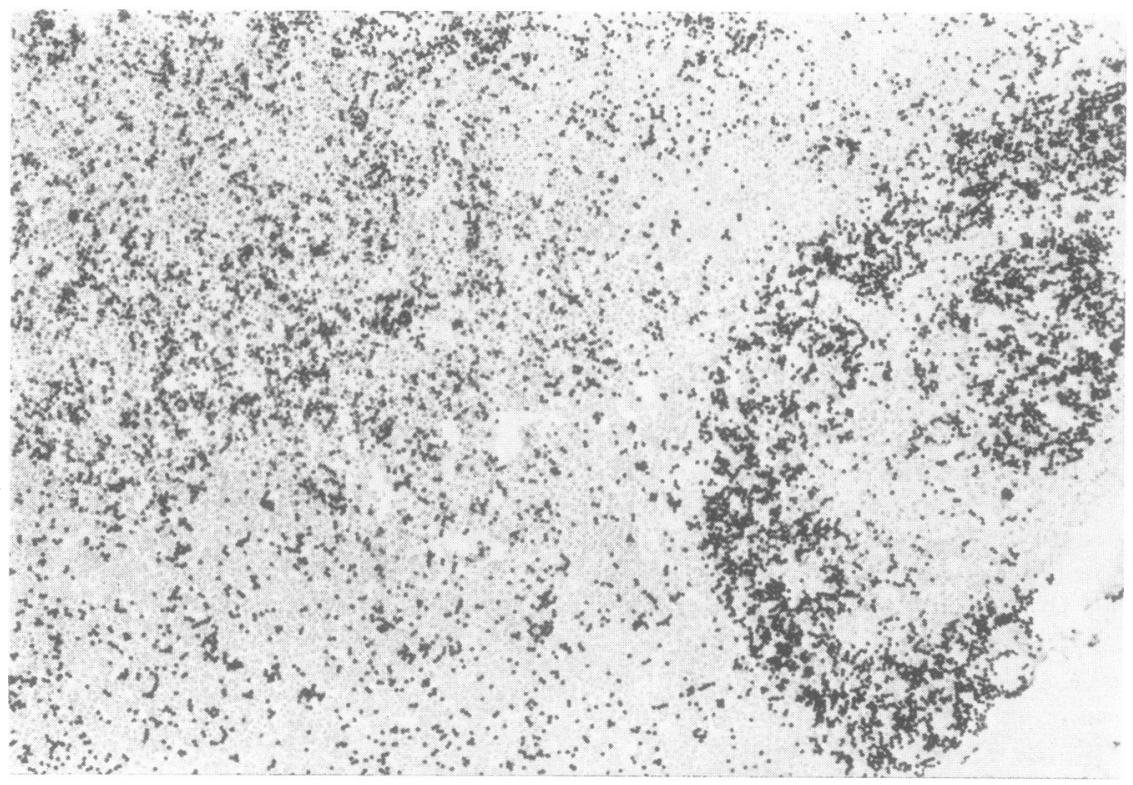

(b)

Fig. 1 Haemadsorption to tissue sections of a thymoma adsorption of $E$ and $E A C 3 b$ indicator cells to cryostat sections $(H$ and $E, \times 112)$. (a) The $E$ cells adhere in a uniform pattern. (b) EAC $3 b$ are scattered throughout the tissue. Note area far right which is negative with $E$ cells and positive with $E A C 3 b$ cells. 


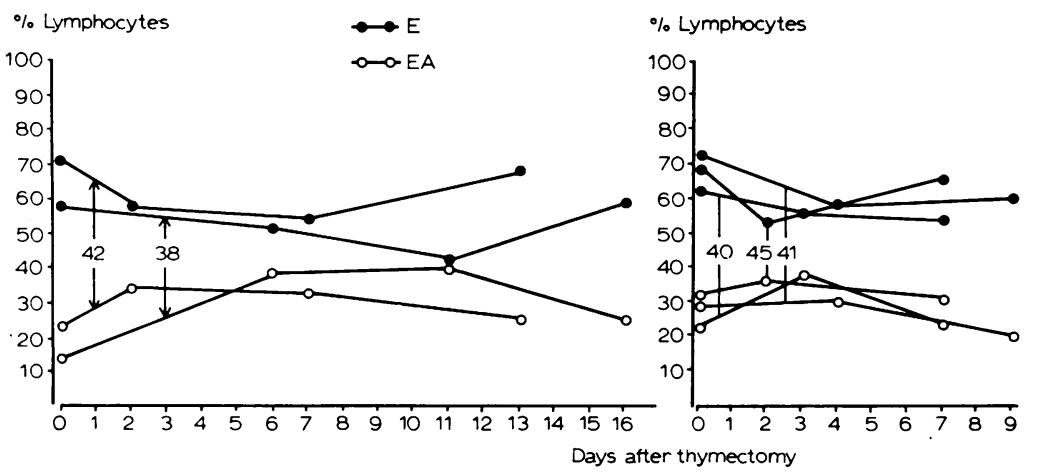

Fig. 2 Results of E- - and $E A-O-O-$ rosette tests with lymphocytes from peripheral blood of five patients with myasthenia gravis before and after thymectomy. Left: $M G 42$ and $M G$ 38, right: $M G 40,41$, and 45 .

pensions of hyperplastic thymus of myasthenia gravis patients were $T$ lymphocytes. This figure is not significantly different from that obtained using cell suspensions of normal thymic tissue. Even in cell suspensions from two thymomas of lymphoepithelial type, the percentage of $T$ lymphocytes was normal. Similar data have also been reported by Abdou et al. (1974) and Shirai et al. (1976), and it can now, presumably, be concluded that the percentage of $\mathrm{T}$ lymphocytes both in thymoma and hyperplastic thymic tissue in myasthenia gravis is normal.

There was, however, a difference in the distribution of $\mathrm{T}$ lymphocytes within the thymus. In the hyperplastic thymus and in the lymphoepithelioma, the $T$ lymphocytes were distributed diffusely throughout the cortex and medulla, whereas in the normal thymus they were predominant in the cortex.

The thymus gland has also a small subpopulation of B lymphocytes (Birnbaum and Tsairis, 1977). Our data indicate that the number of $C$ receptor-carrying thymocytes is higher in the myasthenic thymus than in the normal thymus. Twenty-five per cent and $9 \%$ of the thymocytes from the two hyperplastic thymuses and $14 \%$ of the thymocytes from each of the two lymphoepitheliomas formed rosettes with EAC indicator cells. These percentages are significantly higher than those obtained using cell suspensions of normal thymic tissue. In the normal, and also in the hyperplastic thymus, the $\mathrm{C}$ receptor-carrying cells were not strictly confined to follicles in the medulla, as reported by Staber et al. (1975), but scattered diffusely throughout the tissue. In thymoma sections, however, these cells were clustered in small areas almost devoid of $\mathrm{T}$ lymphocytes and Fc receptor-carrying lymphocytes. These areas were apparently not germinal centres, but their histological nature could not be defined.

In contrast, the percentage of $\mathrm{Fc}$ receptorcarrying lymphocytes, both from the thymoma and the hyperplastic thymic tissue, did not differ significantly from that of normal thymic tissue. The increase in the B lymphocyte subpopulation in the thymic tissue from myasthenia gravis patients consisted mainly of $\mathrm{C}$ receptor-carrying lymphocytes, which in the thymoma occurred in clusters. The relative and absolute numbers of $\mathrm{C}$ and $\mathrm{Fc}$ receptor-carrying lymphocytes in peripheral blood were similar in myasthenia gravis patients and healthy control subjects. The lower level of Fc receptor-carrying lymphocytes reported by Lisak et al. (1976) is presumably accounted for by the use of different techniques by the two groups.

The mean percentage of $T$ lymphocytes in peripheral blood from myasthenia gravis patients was $68 \%$, which is normal. These data agree with those reported by Abdou et al. (1974) and Kalden et al. (1976).

Thymectomy resulted in a slight decrease in circulating $\mathrm{T}$ lymphocytes with a corresponding increase in B lymphocytes. This reaction was transsitory and the values returned gradually to preoperative levels. Similar findings have also been reported by Fritze and Herrmann (1975), Sandilands et al. (1975), and Pudifin and Cox (1976). Björkholm et al. (1975) found that a significant decrease in the number of $T$ lymphocytes might appear several years after thymectomy. However, Bowen and Pabst (1976) found no indication of immuno-deficiency in myasthenia gravis patients who had undergone thymectomy. The long-term effect of thymectomy on the immune competence in patients with myasthenia gravis is still unknown.

This investigation was supported by the Norwegian Research Council for Science and the Humanities, and in part by a grant from the Norwegian Cancer Society.

\section{References}

Abdou, N. I., Lisak, R. P., Zweiman, B., Abraham- 
sohn, I., and Penn, A. (1974). The thymus in myasthenia gravis. Evidence for altered cell populations. New England Journal of Medicine, 291, 1271-1275.

Beutner, E. H., Sepulveda, M. R., and Barrett, E. V. (1968). Quantitation studies of immunofluorescent staining. Bulletin of the World Health Organisation, 39, 587-606.

Birnbaum, G., and Tsairis, P. (1977). Thymic lymphocytes in myasthenia gravis. Annals of Neurology, 1, 331-333.

Björkholm, M., Holm, G., Johansson, B., and Mellstedt, H. (1975). T-lymphocyte deficiency following adult thymectomy in man. Scandinavian Journal of Haematology, 14, 210-215.

Bowen, T., and Pabst, H. F. (1976). Immunologic response in vitro after thymectomy in patients with myasthenia gravis. Canadian Medical Journal, 115, $619-622$.

Böyum, A. (1968). Isolation of mononuclear cells and granulocytes from human blood. Scandinavian Journal of Clinical and Laboratory Investigation, 21, 7789.

Fritze, D., and Herrmann, C. (1975). Leukocyte and lymphoid cell counts in myasthenia gravis. Neurology (Minneapolis), 25, 251-254.

Hallberg, T., Gurner, B. W., and Coombs, R. R. A. (1973). Opsonic adherence of sensitized ox red cells to human lymphocytes as measured by rosette formation. International Archives of Allergy and Applied Immunology, 44, 500-513.

Jondal, H., Holm, S., and Wigzwill, H. (1972). Surface markers on human T and B lymphocytes. I. A large population of lymphocytes forming nonimmune rosettes with sheep red blood cells. Journal of Experimental Medicine, 136, 207-215.

Kalden, J. R., Lohmann, E., Peter, H. H., and Hilger, C. (1976). Antibody-dependent cellular cytotoxicity and $\mathrm{B}$ - and T-cell activity in the peripheral blood of myasthenia gravis patients. Annals of the New York Academy of Sciences, 274, 421-433.

Lindstrom, J., Lennon, V., Seybold, M. E., and Whittingham, S. (1976). Experimental autoimmune myasthenia gravis and myasthenia gravis: biochemical and immunochemical aspects. Annals of the New York Academy of Sciences, 274, 254-274.

Lisak, R. P., Abdou, N. I., Zweiman, B., Zmijewski, C., and Penn, A. (1976). Aspects of lymphocyte function in myasthenia gravis. Annals of the New York Academy of Sciences, 274, 402-410.

Matre, R., and Tönder, O. (1976). Complement receptors in human renal glomeruli. Scandinavian Journal of Immunology, 5, 437-441.

Pudifin, D. J., and Cox, J. (1976). Lymphocyte subpopulations after thymectomy. Lancet, 1, 1299.

Richman, D. P., Patrick, J., and Arnason, B. W. R. (1976). Cellular immunity in myasthenia gravis: response to purified acetylcholine receptor and autologous thymocytes. New England Journal of Medicine, 294, 694-698.

Sandilands, G. P., Gray, K., Cooney, A., Anderson, J. R., Simpson, J. A., and Behan P. O. (1975). Rosette tests following thymectomy. Lancet, 1 , 171-172.

Shirai, T., Miyata, M., Nakase, A., and Itoh, T. (1976). Lymphocyte subpopulation in neoplastic and nonneoplastic thymus and in blood of patients witho myasthenia gravis. Clinical and Experimental Immunology, 26, 118-123.

Staber, F. G., Fink, U., and Sack, W. (1975). B lymphocytes in the thymus of patients with my asthenia gravis. New England Journal of Medicine, 292, 1032-1033.

Tönder, O., Morse, P. A., and Humphrey, L. J. (1974). Similarities of Fc receptors in human malignant tissue and normal lymphoid tissue. Journal of Immunology, 113, 1162-1169. 